\title{
Koncepcja polskiej lokomotywy spalinowej z hybrydowym układem napędowym
}

\begin{abstract}
Artykut jest poświęcony zagadnieniom zwiazanym z zastosowaniem hybrydowych układów napędowych w lokomotywach spalinowych przeznaczonych do prac manewrowych i prowadzenia lekkich pociagów towarowych. Przedstawiono $w$ nim korzyści wynikajace z wprowadzenia napędu hybrydowego oraz zaprezentowano będqce w eksploatacji lokomotywy użytkowane za granica. Ponadto $w$ referacie przedstawiono wytyczne $i$ wymagania $w$ stosunku do głównych zespołów i urzadzeń napędu hybrydowego oraz wstęne koncepcje krajowych lokomotyw hybrydowych zbudowanych na bazie manewrowych lokomotyw spalinowych typu 6Di, 401Da i TEM2. W zakończeniu przedstawiono koncepcje przewidywane do osiagnięcia po wprowadzeniu napędów hybrydowych $w$ krajowych lokomotywach spalinowych. Referat zastat przygotowany $w$ ramach realizowanego projektu rozwojowego NR 10 0062-10/2011 $p t$,Lokomotywa manewrowa $z$ hybrydowych układem napędowym z wykorzystaniem wysokowydajnych zasobników energii”
\end{abstract}

\section{Wprowadzenie}

W ostatnich latach coraz częściej zwraca się uwage na minimalizacje oddziaływania szkodliwego pojazdów szynowych, w tym lokomotyw spalinowych na środowisko naturalne. Oprócz ograniczenia zużycia energii ( $w$ tym zmniejszenie zużycia jednostkowego paliwa i środków smarnych) dąży się również do redukcji zanieczyszczeń środkami toksycznymi i gazami cieplarnianymi emitowanych do środowiska naturalnego, przede wszystkim przez silniki spalinowe.

Jednym ze sposobów ograniczenia negatywnego oddziaływania na środowisko naturalne jest zastosowane $\mathrm{w}$ eksploatacji pojazdów trakcji spalinowej napędów hybrydowych.

Z doświadczeń krajów wysoko uprzemysłowionych wprowadzenie napędów hybrydowych (układów napędowych z minimum dwoma źródłami energii) przyniosło $\mathrm{w}$ eksploatacji lokomotyw spalinowych następujące korzyści $[1,2,4]$ :

- zmniejszenie do $60 \%$ zużycia paliwa

- odzysk do $40 \%$ energii wykorzystywanej w procesie hamowania

- ograniczenie o $40 \%$ emisji gazów cieplarnianych $\left(\mathrm{CO}_{2}\right.$ i $\left.\mathrm{HC}\right)$ do atmosfery

- zmniejszenie o $10 \%$ emisji CO i NOx oraz cząstek stałych do atmosfery

- redukcję poziomu hałasu zewnętrznego i wewnętrznego w kabinach sterowniczych

- obniżenie poziomu drgań w kabinach sterowniczych

- obniżenie kosztów eksploatacji i utrzymania
Ponadto zastosowanie napędów hybrydowych w lokomotywach spalinowych zwłaszcza pracujących w ruchu manewrowym pozwalać będzie na pełne wykorzystanie mocy silników trakcyjnych, optymalną pracę silnika spalinowego, dłuższe przebiegi i czas pracy silników spalinowych oraz wyraźna poprawę komfortu jazdy.

W pojazdach trakcji spalinowej stosowane są zasadniczo dwa rodzaje układów hybrydowych - szeregowy i równoległy [2], przy czym napędy trakcyjne mogą być zasilane wyłącznie z akumulatorów lub wykorzystywać tylko silnik spalinowy. Można również wykorzystywać oba źródła energii jednocześnie.

Najbardziej racjonalnym układem napędu hybrydowego w zastosowaniu do lokomotyw spalinowych jest układ szeregowy ponieważ silnik spalinowy może pracować na węższym zakresie obrotów, unika się szybkich zmian prędkości i obciążeń oraz dodatkowej emisji składników toksycznych spalin do atmosfery, silnik pracuje w optymalnym zakresie, a jego jednostkowe zużycie oleju napędowego jest najmniejsze a ponadto zasięg ciagniętych pociaggów jest duży - mimo malej mocy zainstalowanego zespołu prądotwórczego.

Dalszą część prezentowanego referatu będzie poświęcona ogólnej prezentacji układów hybrydowych stosowanych w pojazdach drogowych i szynowych z napędem spalinowym oraz koncepcje zabudowy układów hybrydowych $\mathrm{w}$ modernizowanych spalinowych lokomotywach przewidzianych do prac manewrowych oraz prowadzenia lekkich pociagów towarowych i osobowych. 
Prace związane $\mathrm{z}$ przygotowaniem koncepcji i założeń konstrukcyjnych napędów hybrydowych w zastosowaniu do lokomotyw serii SM42 i typu 401Da oraz TEM2 zostały rozpoczęte $\mathrm{w}$ połowie 2011 r. w Instytucie Pojazdów Szynowych „Tabor” w Poznaniu.

\section{Przegląd hybrydowych ukladów napędowych drogowych i szynowych pojazdów $z$ napędem spalinowym.}

W pojazdach drogowych układy napędu hybrydowego stosowane są $\mathrm{w}$ autobusach miejskich i służą przede wszystkim do odzysku energii hamowania a następnie jej wykorzystaniu podczas ruszania i przyspieszania pojazdu. W autobusach miejskich stosowane są układy hybrydowe szeregowe, równoległe i mieszane [2].

Przykładami hybryd autobusowych są między innymi autobusy Mercedes Benz Citaro, MAN Lion, Volvo 7700 oraz Solaris Urbino 18 Hybrid II generacji. Widoki wybranych autobusów z układami hybrydowymi przedstawiono na rys.1 i 2 a ich główne parametry w tablicy 1 .

a)

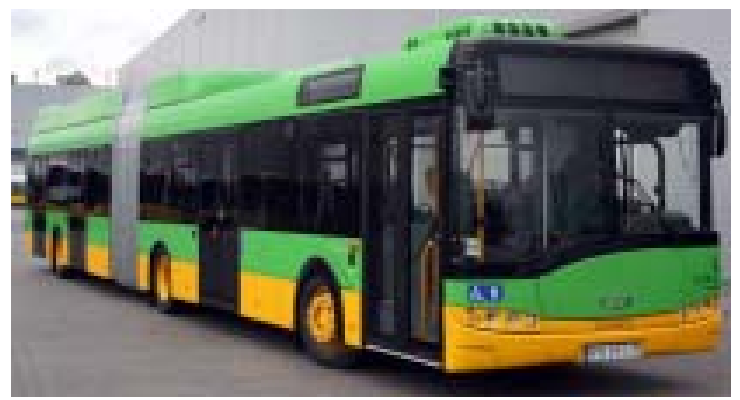

b)

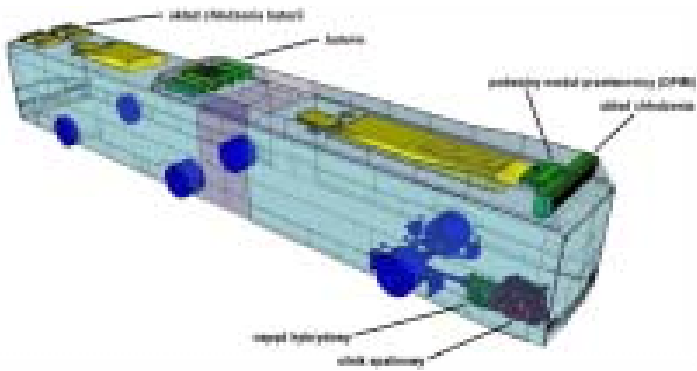

Rys.1 Autobus miejski Solaris Urbino 18 Hybrid II generacji (a) oraz rozmieszczenie w nim zespołów i urządzeń układu hybrydowego (mieszanego) (b)

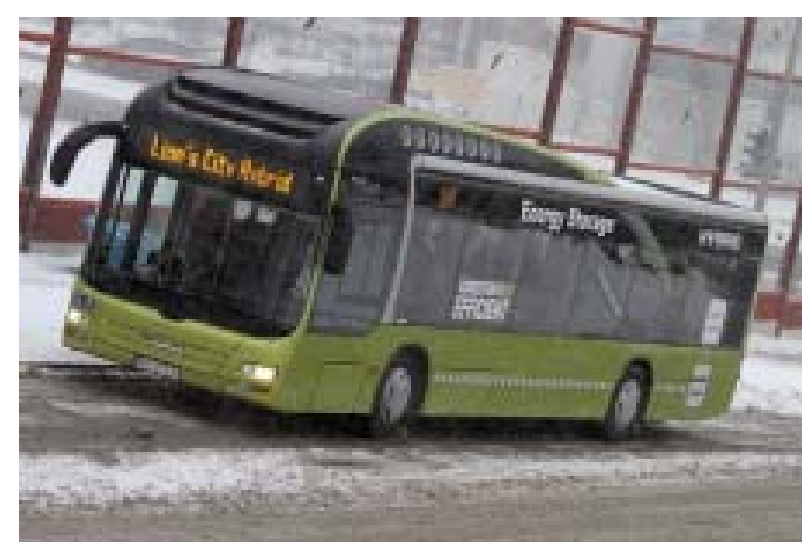

Rys.2 Autobus miejski firmy MAN typu Lions City z układem hybrydowym

Należy również wspomnieć o napędach hybrydowych stosowanych $\mathrm{w}$ trolejbusach, tramwajach oraz elektrycznych zespołach trakcyjnych w których stosowane są układy związane $\mathrm{z}$ odzyskiwaniem energii uzyskiwanej najczęściej podczas procesu hamowani oraz jej akumulowanie, w wysokowydajnych zasobnikach energii $[1,2,3]$.

Dość późno rozpoczęto wprowadzanie układach napędowych w spalinowych pojazdach szynowych. Przesłankami decydującymi o ich wprowadzeniu była poprawa oddziaływania na środowisko naturalne oraz obniżenie zużycia paliwa. Najczęściej napędy hybrydowe stosowane są w lokomotywach spalinowych poddanych procesom modernizacyjnym lub odnowy, chociaż w ostatnich okresie rozpoczęto budowę nowych lokomotyw spalinowych przeznaczonych przede wszystkim do prac manewrowych i prowadzenia lekkich pociagów towarowych i osobowych.

Największe doświadczenie w wdrażaniu hybrydowych układów napędowych ma firma Railpower Technologies Corp, która zmodernizowała i przerobiła już kilkadziesiąt sztuk lokomotyw manewrowych i liniowych w większości starego typu i wycofanych $\mathrm{z}$ eksploatacji. W lokomotywach tych napęd hybrydowy tworzy zespół prądotwórczy (silnik spalinowy + prądnica synchroniczna) oraz ładowane przez niego

Tablica 1 Parametry techniczne autobusów z napędami hybrydowymi

\begin{tabular}{|l|c|c|c|}
\hline \multicolumn{1}{|c|}{ Parametr $\backslash$ typ autobusu } & Jelcz PR110 Lublin & Skoda 21TrACI & Solaris Trollino 18 \\
\hline Moc agregatu prądotwórczego & - & $100 \mathrm{~kW}$ & $100 \mathrm{~kW}$ \\
\hline Moc superkondensatorów & $0.75 \mathrm{kWh}$ & - & $0.61 \mathrm{kWh}$ \\
\hline Akumulatory & $6 \mathrm{kWh}$ & - & - \\
\hline Zasięg autobusu bez trakcji & $2-3 \mathrm{~km}$ & nieograniczony & $\begin{array}{c}400 \mathrm{~m} / \text { nieograniczo } \\
\text { ny }\end{array}$ \\
\hline Masa własna & $11600 \mathrm{~kg}$ & $11850 \mathrm{~kg}$ & $18500 \mathrm{~kg}$ \\
\hline Liczba miejsc ogółem/siedz. & $110 / 36$ & $86 / 26$ & $171 / 48$ \\
\hline Wymiary d/s/w & $12000 / 2500 / 3480 \mathrm{~mm}$ & $11760 / 2500 / 3365 \mathrm{~mm}$ & $\begin{array}{c}18000 / 2550 / 3220 \\
\mathrm{~mm}\end{array}$ \\
\hline Typ silnika spalinowego & Elmor DK210A3P & b.d. & CEGELEC \\
\hline Moc silnika spalinowego & $110 \mathrm{~kW}$ & $140-175 \mathrm{~kW}$ & $288 \mathrm{~kW}$ \\
\hline
\end{tabular}


wysokowydajne zasobniki energii. Energia z zasobników poprzez przekształtnik trakcyjny zasila silniki trakcyjne. W zależności od zapotrzebowania na energię silniki trakcyjne mogą być zasilane z zasobników, prądnicy głównej lub $\mathrm{z}$ obu źródeł jednocześnie, przy czym optymalnym wykorzystaniem energii steruje układ mikroprocesorowy.

Modułową konstrukcję lokomotyw firmy Railpower Technologies Corp przedstawiono na rys.3 a ideę działania napędu hybrydowego na rys.4

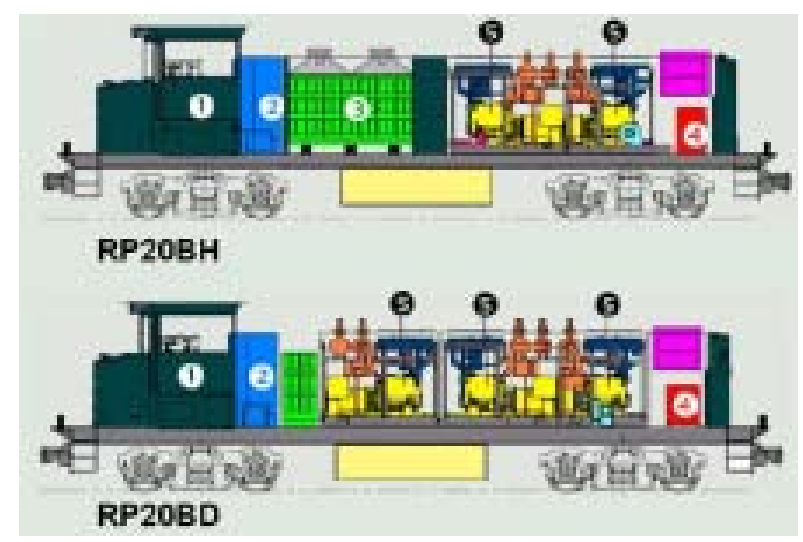

Rys.3 Modułowe konstrukcje liniowych lokomotyw hybrydowych firmy Railpower Technologies Corp 1-kabina maszynisty, 2przedział elektryczny, 3-zasobniki energii, 4-przedział pneumatyczny, 5-agregaty prądotwórcze

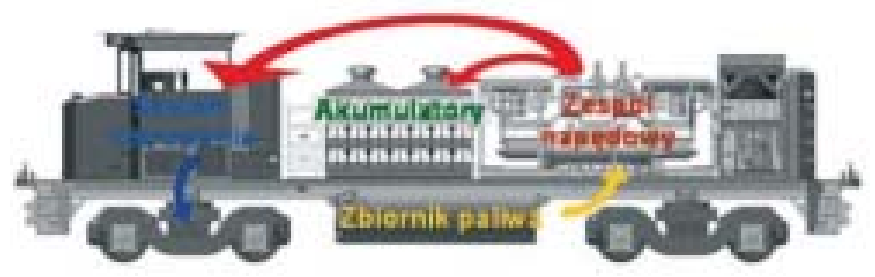

Rys.4 Idea działania napędu hybrydowego konstrukcji Railpower Technologies Corp

Innymi przykładami spalinowych lokomotyw hybrydowych są lokomotywy firmy Alstom wyposażone w oszczędny i ekologiczny generator $\mathrm{z}$ silnikiem wysokoprężnym, który ładuje akumulatory i może być wykorzystywany również bezpośrednio do napędu silników trakcyjnych przy ekstremalnych obciążeniach. Lokomotywy mogą pracować zasadniczo w ruchu manewrowym, jak i liniowych.

Widok ogólny tych lokomotyw przedstawiono na rys. 5 i 6 .

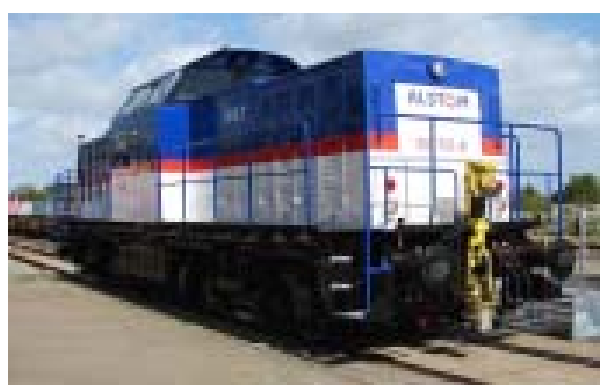

Rys.5 Hybrydowa lokomotywa spalinowa serii BR203 firmy Alstom

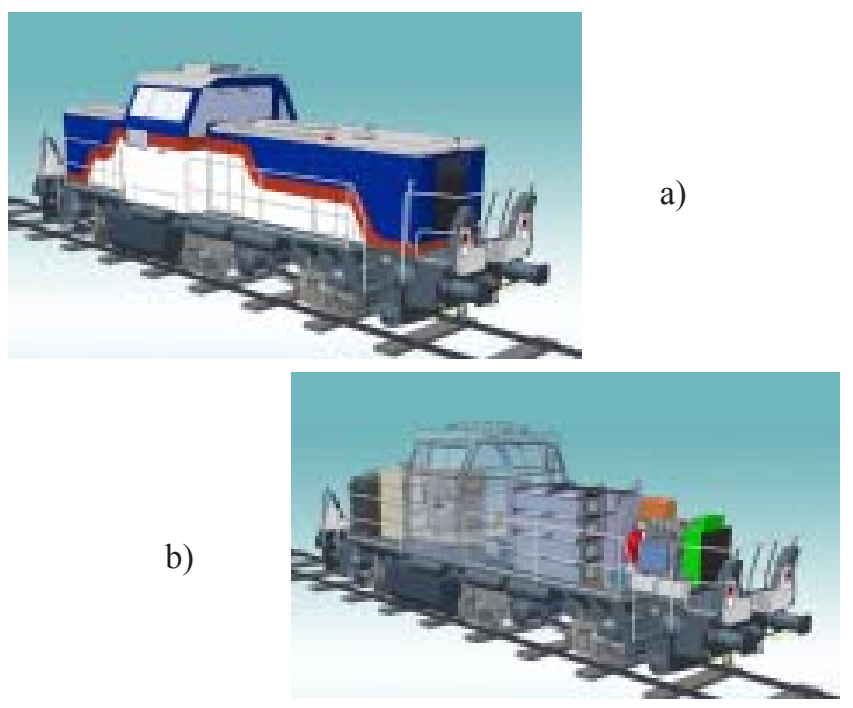

Rys.6 Hybrydowa lokomotywa spalinowa typu $\mathrm{H} 3$ firmy Alstom a-widok ogólny, b-rozmieszczenie maszyn i urządzeń w lokomotywie

Podobna w budowie jest lokomotywa typu H300 o układzie osi Bo-Bo zaprojektowana w zakładach Toshiba w Japonii do obsługi terminali towarowych w Tokio [3]. Widok ogólny lokomotywy przedstawiono na rys. 7 .

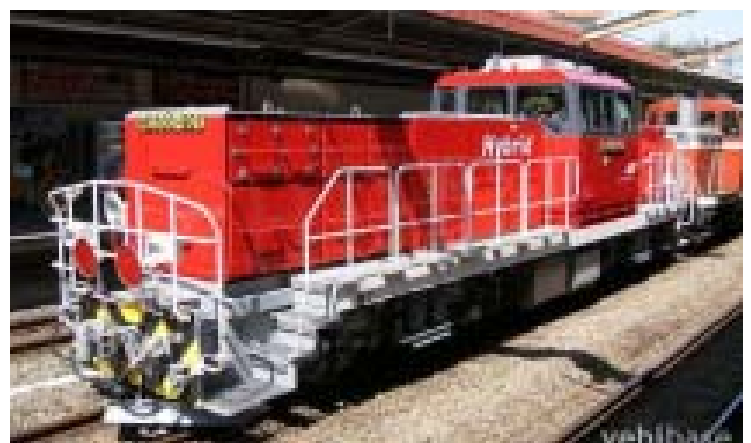

Rys.7 Hybrydowa lokomotywa manewrowa typu HD 300 firmy Toshiba

Innymi ciekawymi rozwiązaniami lokomotyw hybrydowych jest ciężka lokomotywa towarowa o mocy 4400 kM (a dzięki magazynowanej energii w akumulatorach moc można podnieść do $6400 \mathrm{kM}$ ) wykonana w firmie General Electronic [2] oraz lokomotywa typu BREam 923 o układzie osi Bo dla kolei szwajcarskich, która napędzana jest zarówno przez zespół prądotwórczy z silnikiem spalinowym o mocy $360 \mathrm{~kW}$ lub z sieci trakcyjnej prądu przemiennego o napięciu $15 \mathrm{kV} / 16,7 \mathrm{~Hz}$ (lub $25 \mathrm{kV} / 50 \mathrm{~Hz}$ ). Przy zasilaniu $\mathrm{z}$ sieci moc lokomotywy może wzrosnąć nawet do $1500 \mathrm{~kW}[2,3]$. Widoki ogólne lokomotyw przedstawiono na rys.8 $\mathrm{i} 9$. 
a)

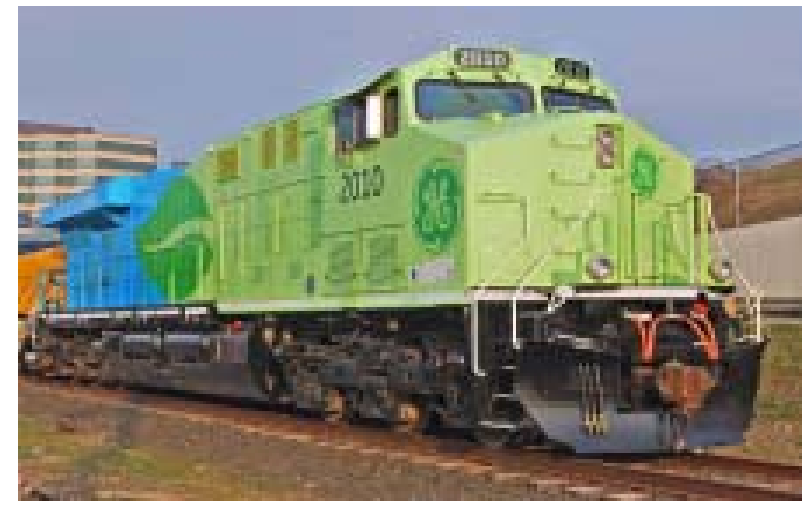

b)
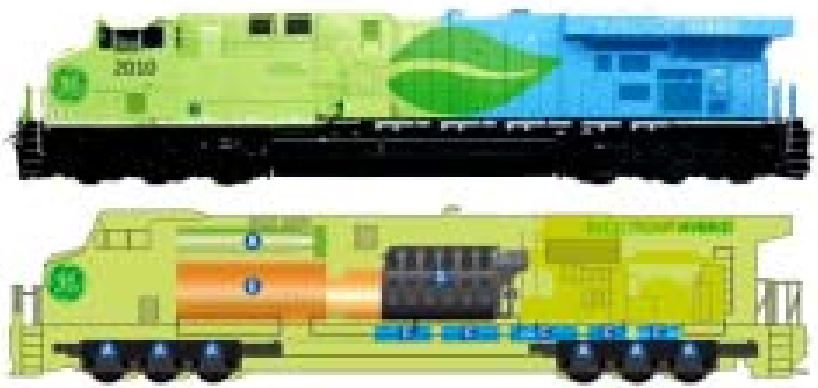

Rys. 8 Spalinowa lokomotywa hybrydowa typu 2010GE GE Evolution Hybrid firmy General Electric (a-widok ogólny, rozmieszczenie maszyn i urządzeń)

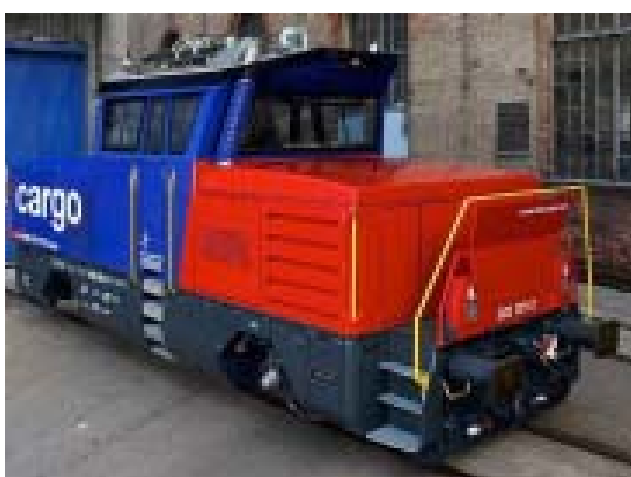

Rys.9 Hybrydowa lokomotywa kolei szwajcarskiej BR Eem 923

Ogólne parametry wybranych spalinowych lokomotyw hybrydowych przedstawiono w tablicy 2.

\section{Koncepcje krajowych spalinowych lokomotyw manewrowych $z$ hybrydowymi układami na- pędowymi.}

Zaniechanie produkcji nowoczesnych lokomotyw spalinowych w kraju zdecydowało o rozpoczęciu procesu ich modernizacji prowadzonej w ramach napraw głównych. Dotyczyło to początkowo lokomotyw manewrowych, a w ostatnim okresie również

Tablica 2 Podstawowe parametry techniczne hybrydowych lokomotyw spalinowych

\begin{tabular}{|c|c|c|c|c|c|c|c|}
\hline \multirow{2}{*}{$\mathrm{Lp}$} & \multicolumn{2}{|r|}{ Lokomotywy } & \multirow{2}{*}{$\begin{array}{l}\text { Moc silnika } \\
\text { spalinowego }\end{array}$} & \multirow{2}{*}{$\begin{array}{l}\text { Moc zmagazyno- } \\
\text { wana } \\
\text { w akumulatorach }\end{array}$} & \multirow{2}{*}{ Rodzaj użytych baterii } & \multirow{2}{*}{$\begin{array}{l}\text { Prędkość } \\
\text { maksy- } \\
\text { malna }\end{array}$} & \multirow{2}{*}{ Układ osi } \\
\hline & Typ & Producent & & & & & \\
\hline 1. & $\begin{array}{c}\text { Evolution } \\
\text { Hybrid }\end{array}$ & General Electric & $4400 \mathrm{KM}$ & $1471 \mathrm{~kW}$ & - & $120 \mathrm{~km} / \mathrm{h}$ & $\mathrm{Co}-\mathrm{Co}$ \\
\hline 2. & BR203 & Alstom & $238 \mathrm{~kW}$ & - & $\begin{array}{c}\text { Baterie akumulatorów } \\
\text { firmy Hoppecke }\end{array}$ & $60 \mathrm{~km} / \mathrm{h}$ & Bo-Bo \\
\hline 3. & GK10B & $\begin{array}{c}\text { Railpower } \\
\text { Technologies Corp }\end{array}$ & $120 \mathrm{KM}$ & - & $\begin{array}{l}\text { 700V DC 600Ah typu } \\
\text { VRLA }\end{array}$ & & Bo-Bo \\
\hline 4. & GG20B & $\begin{array}{c}\text { Railpower } \\
\text { Technologies Corp }\end{array}$ & $268 \mathrm{KM}$ & - & $\begin{array}{l}\text { 700V DC 1200Ah typu } \\
\text { VRLA }\end{array}$ & & Bo-Bo \\
\hline 5. & RP20BH & $\begin{array}{c}\text { Railpower } \\
\text { Technologies Corp } \\
\end{array}$ & $\begin{array}{c}\text { (2 silniki) } \\
667 \mathrm{KM} \\
\end{array}$ & - & $\begin{array}{c}700 \text { V DC 600Ah typu } \\
\text { VRLA }\end{array}$ & & Bo-Bo \\
\hline 6. & RP20BD & $\begin{array}{c}\text { Railpower } \\
\text { Technologies Corp } \\
\end{array}$ & $\begin{array}{l}\text { (3 silniki) } \\
667 \mathrm{KM} \\
\end{array}$ & - & - & & Bo-Bo \\
\hline 7. & 64Z/Desiro & $\begin{array}{l}\text { MTU Friedrichshafen } \\
\text { GmbH }\end{array}$ & $315 \mathrm{~kW}$ & $400 \mathrm{~kW}$ & - & & - \\
\hline 8. & $\begin{array}{l}\text { KiHa E200 } \\
\text { DEMU }\end{array}$ & Hitachi & $331 \mathrm{~kW}$ & - & $\begin{array}{c}16 \text { wysokowydajnych } \\
\text { akumulatorów litowo } \\
\text { jonowych pojemności } \\
15.2 \mathrm{Ah}\end{array}$ & $100 \mathrm{~km} / \mathrm{h}$ & Bo-Bo \\
\hline 9. & H3 & Alstom & $\begin{array}{c}\text { Wersja } \\
\text { pierwsza - } \\
700 \mathrm{~kW} \\
\text { Wersja druga - } \\
2 \text { silniki o } \\
\text { łącznej mocy } \\
700 \mathrm{~kW} \\
\text { Wersja trzecia } \\
\text { - } 1000 \mathrm{~kW} \\
\end{array}$ & - & - & $100 \mathrm{~km} / \mathrm{h}$ & $\begin{array}{l}\text { Ao-Ao- } \\
\text { Ao }\end{array}$ \\
\hline 10. & HD300-901 & Toshiba & - & - & - & $110 \mathrm{~km} / \mathrm{h}$ & Bo-Bo \\
\hline 11. & ALP-45DP & Bombardier & $4200 \mathrm{KM}$ & - & - & $\begin{array}{c}160 \div 200 \\
\mathrm{~km} / \mathrm{h}\end{array}$ & Bo-Bo \\
\hline
\end{tabular}


lokomotyw liniowych. Szczegółowa analiza eksploatacyjna lokomotyw wykazała również ich małą obciążalność, zwłaszcza $\mathrm{w}$ realizacjach prac manewrowych (nawet do ok. $80 \%$ czasu pracy na biegu jałowym). Celowym więc byłoby wyposażenie tych lokomotyw w wysokowydajne zasobniki energii, co w konsekwencji da zastosowanie nowoczesnych silników spalinowych o mniejszej mocy, mniejszym zużyciu paliwa oraz mniejszą emisją składników toksycznych zawartych w spalinach do atmosfery.

Wśród wielu lokomotyw spalinowych eksploatowanych w kraju procesem hybrydyzacji należałoby objąć lokomotywy manewrowe serii SM42 (zmodernizowane) oraz typu TEM2 (SM48) i 401Da, ponieważ ich liczba jest duża, tak więc wprowadzenie napędów hybrydowych dałoby największe efekty ekonomiczne.

\subsection{Parametry lokomotyw bazowych przewidzia- nych do wyposażenia w napęd hybrydowy}

W pracach nad koncepcją spalinowych lokomotyw manewrowych wyposażonych w układ napędowy hybrydowy przewiduje się wykorzystanie lokomotyw typu 401Da, 6D i TEM2.

Lokomotywa spalinowa typu 401Da jest przewidziana do lekkich i średnich prac manewrowych na stacjach i górkach rozrządowych oraz do prowadzenia lekkich pociągów towarowych i gospodarczych.

Jest lokomotywą wyposażoną w silnik spalinowy o mocy $350 \mathrm{kM}$ i silniki trakcyjne typu Lsa-430 o mocy $173 \mathrm{~kW}$. Układ osi C (z wiązarami i dwoma silnikami trakcyjnymi) umożliwia jazdę z prędkością $60 \mathrm{~km} / \mathrm{h}$. Mimo wykonania około 500 szt. lokomotywy tego typu nie doczekały się żadnej większej i kompleksowej modernizacji.

Lokomotywa spalinowa serii SM42 (typu 6Dg, 6Di, 6Dk) jest typową lokomotywą manewrową a jednocześnie jest wykorzystywana jako lokomotywa (serii SP42 lub SU42) do prowadzenia lekkich pociągów osobowych i towarowych. Bazowa lokomotywa 6D jest wyposażona $\mathrm{w}$ silnik typu a8C22 o mocy $800 \mathrm{kM}$, prądnicę prądu stałego oraz silniki trakcyjne typu Lsa-430 o mocy $173 \mathrm{~kW}$. Układ osi Bo-Bo umożliwia rozwijanie prędkości do $90 \mathrm{~km} / \mathrm{h}$. Obecnie na rynku przewozowym wykorzystywane są lokomotywy typu 6Dg i 6Dk modernizowane przez Newag Nowy Sącz i PESA Bydgoszcz, a w 2012r. wprowadzona zostanie lokomotywa 6Di wyprodukowana przez Fablok Chrzanów. Wszystkie lokomotywy wyposażone zostały w nowoczesne silniki spalinowe, zespół prądnic synchronicznych oraz zmodernizowane nadwozie. Bez zmian pozostało podwozie i układy biegowe (wózki).

Lokomotywa spalinowa typu TEM2 (na PKP znane jako SM48) jest lokomotywą przeznaczoną do realizacji ciężkich prac manewrowych oraz prowadzenia pociagów towarowych.
Bazowa lokomotywa TEM2 jest wyposażona $\mathrm{w}$ silnik spalinowy typu $882 \mathrm{~kW}$, zespół prądnic i silniki trakcyjne prądu stałego. Układ osi Co-Co i prędkość maksymalna $100 \mathrm{~km} / \mathrm{h}$ jest wystarczająca do realizacji zadań trakcyjnych.

Obecnie w eksploatacji są wykorzystywane zmodernizowane lokomotywy TEM2 wyposażone w silniki typu 12V356TC14 i 12V4000R41 firmy MTU i zespół prą̧nic synchronicznych wykonanych przez konsorcjum „Tamara” oraz lokomotywy typu 15D i 16D (na tor normalny i szeroki) wyprodukowane przez Newag Nowy Sącz i wyposażone w silniki spalinowe firmy CAT typu $3512 \mathrm{C}$ o mocy $1480 \mathrm{~kW}$.

Do wprowadzenia nowych lokomotyw zmodernizowanych na bazie TEM-2 przygotowuje się również PESA Bydgoszcz i IPS TABOR Poznań. Przewiduje się wykonanie dwóch wersji lokomotyw jedno i dwuagregatowej $\mathrm{w}$ oparciu o nowoczesne silniki spalinowe firmy MTU o mocach od 690 do $1800 \mathrm{~kW}$ i zespół prądnic synchronicznych. Zachowana zostanie konstrukcja ostoi oraz układy biegowe, przy zmodernizowanych częściowo usprężynowaniu i prowadzeniu zestawów kołowych w ramie wózka.

\subsection{Podstawowe wymagania i wytyczne dla loko- motyw spalinowych z napędami hybrydowymi}

W przewidzianych do modernizacji spalinowych lokomotywach manewrowych wszystkie nowe i modernizowane układy i zespoły związane $\mathrm{z}$ napędem hybrydowym powinny cechować się następującymi wymaganiami i wytycznymi [5]:

- Układ biegowy - bez zasadniczych zmian spełniający wymagania ujęte w normie PNEN 14363:2007, karcie UIC 518 i raporcie $\mathrm{nr}$ 8 ORE (ERRI) B55 w zakresie bezpieczeństwa przed wykolejeniem i oddziaływania na tor

- Układ nadwozia - spełniający wymagania wytrzymałościowe ujęte zasadniczo w normie PN-EN 12663-1:2010 oraz w zakresie kabiny ujęte w TSI „Lokomotywy i wagony pasażerskie"

- Silnik spalinowy - poziom IIIb emisji spalin wg Rozporządzenia MGiP - Dz.U. nr 202 poz $1681 \quad \mathrm{z} \quad 19.08 .2005$ tj. CO $\quad$-max $3,5 \mathrm{~g} / \mathrm{kWh}, \mathrm{HC}+\mathrm{NOx}-\max 4,0 \mathrm{~g} / \mathrm{kWh}$ i cząstki stałe PT -max $0,025 \mathrm{~g} / \mathrm{kWh}$, małe jednostkowe zużycie paliwa i środków smarnych, duża trwałość

- Zespół prądnic - synchroniczne na jednym wale

- Silnik trakcyjny i napęd osiowy - zasadniczo bez zmian

- Zasobniki energii - baterie litowo-żelowo polimerowe lub niklowo-kadmowe, napięcie zbliżone do napięcia znamionowego silników trakcyjnych, pojemność na min $2 \mathrm{~h}$ pracy a 
- trwałość 1000 cykli, gęstość energii $40 \mathrm{kWh} / \mathrm{kg}$, masa i gabaryty - dobór indywidualny do danego typu lokomotywy

- Układ sterowania układu hybrydowego i lokomotywy - mikroprocesorowy z pełną diagnostyką i możliwością rejestracji wszystkich parametrów pracy

- Układ przekształtnika trakcyjnego - możliwość zasilania z prądnicy, zasobnika i obu źródeł jednocześnie, masa i gabaryty w zależności od typu i mocy lokomotywy

- Układ ładowania i rozładowania zasobników - możliwość ładowania z prądnicy i obcego (zewnętrznego) źródła, czas ładowania poniżej 5h, pełna kontrola rozładowania i pełna diagnostyka $\mathrm{w}$ zakresie parametrów prą̧owo-napięciowych, temperatur i energii, masa i gabaryty w zależności od wielkości zasobników

Oczywistym jest, że szczegółowe parametry poszczególnych zespołów i układów hybrydowych zależne będą od typu (serii) lokomotywy przeznaczonej do ich zabudowy.

\subsection{Wstępne koncepcje lokomotyw $z$ napędami hybrydowymi}

Największy i racjonalny efekt uzyska się wprowadzając układy napędu hybrydowego w modernizowanych lokomotywach w których dodatkowo zabuduje się (w miejsce silnika dużej mocy) nowy zespół prądotwórczy o mniejszej mocy o około $70-80 \%$ spełniający najnowsze wymagania w zakresie zużycia paliwa i środków smarnych oraz wymagania $\mathrm{w}$ zakresie emisji składników toksycznych spalin, w tym $\mathrm{CO}_{2}, \mathrm{HC}$, NOx i cząstek stałych do atmosfery.

$\mathrm{W}$ proponowanych lokomotywach zakłada się zastosowanie szeregowego układu napędu hybrydowego, w którym silnik spalinowy poprzez prądnice synchroniczną i prostownik ładuje wysokowydajne zasobniki energii. Po naładowaniu zasobniki zasilaja silniki trakcyjne. W proponowanej wstępnej koncepcji zakłada się zwiększoną ilość baterii o pojemnościach gwarantujących rozwijanie pełnej mocy przez silniki trakcyjne. Dodatkowo w koncepcji założono również możliwość wykorzystania do ładowania zasobników, energii odzyskiwanej w procesie hamowania, z zewnętrznego źródła prądu lub z zbudowanego (jako jeden $z$ wariantów) odbieraka prądu pod- czas eksploatacji pod siecią trakcyjną.

Ogólny (wstępny) schemat blokowy napędu hybrydowego dla wszystkich branych pod uwagę lokomotyw przedstawiono na rys. 10 .

W koncepcji nie należy wykluczać zastosowania równoległego (lub mieszanego) układu napędu hybrydowego jak również zabudowy dwóch lub trzech zespołów prą̧otwórczych oraz zabudowy kilku segmentów wysokowydajnych zasobników energii. Do dyspozycji mamy między innymi akumulatory ołowiowo-kwasowe, niklowo-kadmowe, niklowometalowo-wodorkowe firmy Hoppecke, ogniwa ołowiowe i baterie niklowo-kadmowe firmy Hawker oraz akumulatory niklowo-kadmowe firmy Ferak.

Dla lokomotywy typu 401Da można skompletować zasobniki z akumulatorów firmy Hawker typu „Odessey” o pojemności 42Ah, prądzie rozruchowym 550A, pracujących $\mathrm{w}$ temperaturze od -60 do $+70^{\circ} \mathrm{C}$. Oczywistym jest, że lokomotywy typu $401 \mathrm{Da}$ wymagać będą pełnej modernizacji nadwozia tj. przedziałów maszynowych i kabiny sterowniczej z zastosowaniem modułowej konstrukcji poszczególnych sekcji modułów.

Widok ogólny lokomotywy typu 401Da z układem napędu hybrydowego przedstawiono na rys.11.
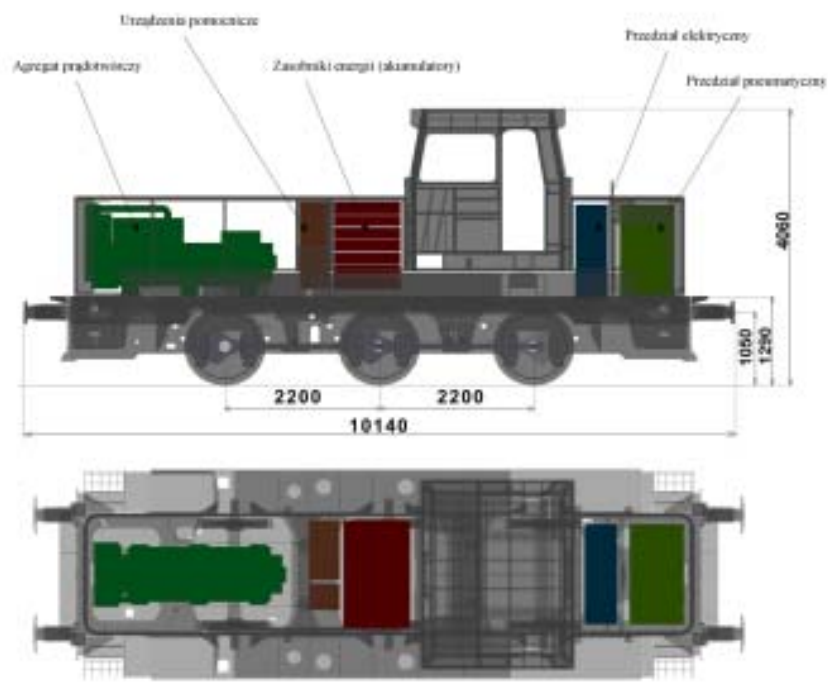

Rys.11 Ogólny widok wraz z rozmieszczeniem zespołów i urządzeń w lokomotywie typu 401Da z hybrydowym układem napędowym

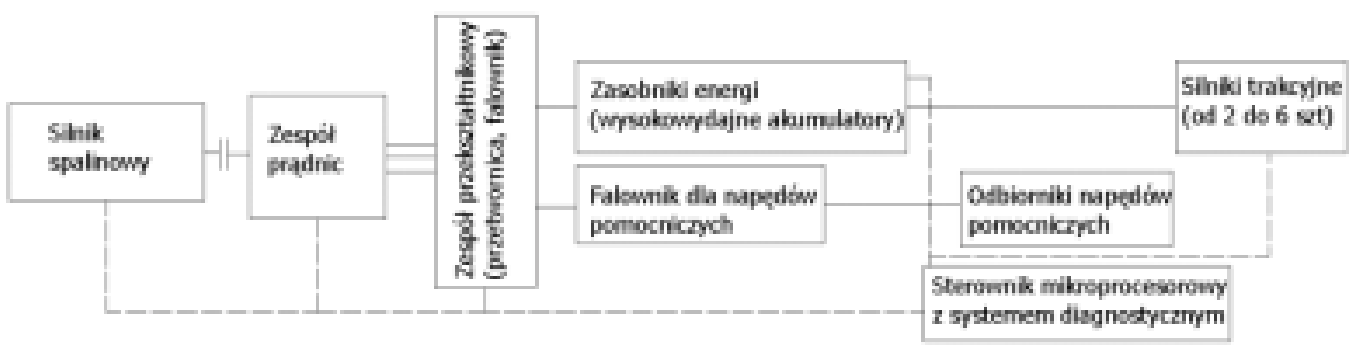

Rys. 10 Wstępny schemat blokowy napędu hybrydowego spalinowej lokomotywy manewrowej 

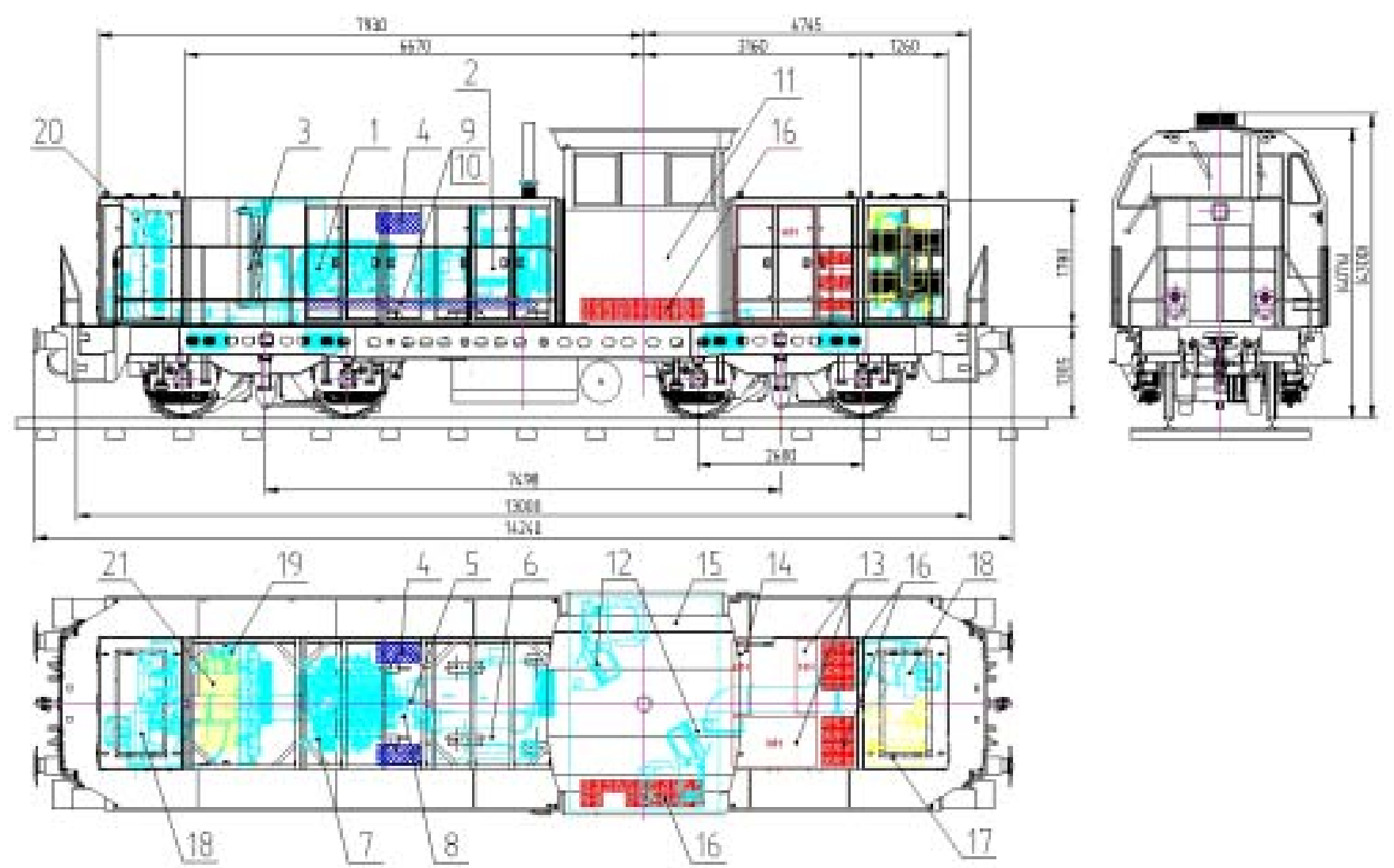

Rys.12 Ogólny widok wraz z rozmieszczeniem zespołów i urządzeń w lokomotywie typu 6Di z hybrydowym układem napędowym

1. Silnik spalinowy, 2. Zespót prądnic synchronicznych, 3. Chłodnica / wentylator, 4. Filtr powietrza, 5. Rury wydechowe, 6. Thumik wydechu, 7. Rury powietrza doładowania, 8. Sprzęło główne, 9. Rama podsilnikowa / amortyzator, 10.Belka podsilnikowa, 11.Kabina maszynisty, 12.Pulpity sterownicze, 13.Szafy WN, NN, 14.Tablica NN, 15.Skrzynia prostowników $/$ falowników, 16.Skrzynia akumulatorów, 17.Tablica pneumatyczna, 18. Wentylatory silników trakcyjnych , 19.Podgrzewacz Webasto, 20.Agregat sprężarkowy, 21.Wylot powietrza z chtodnicy

Dla lokomotyw typu TEM2 koncepcja zabudowy układu napędu hybrydowego będzie podobna do koncepcji rozwijanej z wykorzystaniem zmodernizowanej lokomotywy spalinowej typu 6Di.

\section{Podsumowanie}

Układy napędów hybrydowych dla spalinowych lokomotyw manewrowych ( $\mathrm{w}$ przyszłości również liniowych) to z jednej strony obniżenie kosztów eksploatacji, z drugiej natomiast zmniejszenie ich szkodliwego oddziaływania na środowisko naturalne.

Obecnie w Instytucie Pojazdów Szynowych „TABOR” w Poznaniu prowadzi się prace wstępne i koncepcyjne nad zastosowaniem układów napędu hybrydowego w spalinowych lokomotywach manewrowych. Należy oczekiwać, że wprowadzenie napędów hybrydowych przyniesie wymierne efekty ekonomiczno-ekologiczne, przy czym będą one wyższe im więcej lokomotyw będzie zmodernizowanych. Oczywistym jest, że na pewno obniży się zużycie paliwa, szkodliwa emisja składników toksycznych do atmosfery oraz hałas i drgania, a także zwiększy się niezawodność zespołów.
Dokładne wartości oczekiwanych efektów będą ustalone dopiero po zbudowaniu lokomotyw z układami napędu hybrydowego oraz po przeprowadzeniu prób i badań w tym wielomiesięcznych prób eksploatacyjnych.

\section{Literatura.}

[1] Marciniak Z.; Hybrydowe uktady napędowe lokomotyw spalinowych. Logistyka, 2010, $n r 4$.

[2] Marciniak Z.; Napędy hybrydowe pojazdów trakcji elektrycznej i spalinowej. Pojazdy Szynowe, 2011, $n r 4$.

[3] Praca zbiorowa: Przeglad pojazdów trakcyjnych (elektrycznych $i$ spalinowych) z hybrydowymi uktadami napędowymi. Opracowanie OR-10111, IPS TABOR Poznań, 09.2011.

[4] Praca zbiorowa: Analiza konstrukcyjna i eksploatacyjna lokomotyw spalinowych $z$ hybrydowymi uktadami napędowymi. Opracowanie OR-10112, IPS TABOR Poznań, 09.2011.

[5] Praca zbiorowa. Wytyczne i wymagania dla głównych zespotów i urzqdzeń napędów hybrydowych. Opracowanie OR-10127, IPS TABOR Poznań, 02.2012. 